\title{
Decolorization of Reactive Red 239 Using UV-C Activated Peroxydisulfate
}

\author{
Ozlem Esen Kartal* \\ Department of Chemical Engineering, Inonu University, Malatya, Turkey
}

Received: 3 May 2018

Accepted: 7 August 2018

\begin{abstract}
Decolorization of Reactive Red 239 (RR239) using a sulfate radical ( $\mathrm{SO}_{4}^{-}$)-based advanced oxidation process was investigated in a batch photoreactor. $\mathrm{SO}_{4}^{--}$was generated in situ through activation of peroxydisulfate under UV-C illumination. Effect of initial $\mathrm{pH}$ (3-9), initial dye concentration (20-50 $\left.\mathrm{mg} \mathrm{dm}^{-3}\right), \mathrm{S}_{2} \mathrm{O}_{8}{ }^{2-}$ dosage $\left(0-3 \mathrm{mmol} \mathrm{dm}^{-3}\right)$ and lamp power $(0-16 \mathrm{~W})$ were explored. It was found that initial $\mathrm{pH}$ of RR239 solution had no considerable effect on decolorization efficiency. Experimental results demonstrated that decolorization efficiency enhanced with increasing $\mathrm{S}_{2} \mathrm{O}_{8}{ }^{2-}$ dosage and lamp power and decreasing initial dye concentration. Quenching experiments were performed with alcohols to determine the dominant radical. Under the conditions tested in this study, $98 \%$ and $70 \%$ decolorization and aromatic degradation efficiencies were obtained within $120 \mathrm{~min}$ of irradiation time, respectively. Decolorization and aromatic degradation efficiencies of RR239 in PS/UV-C and PMS/UV-C systems were evaluated in terms of electrical energy consumption per order by figure of merit approach.
\end{abstract}

Keywords: azo dye, sulfate radical, decolorization, quenching, electrical energy consumption

\section{Introduction}

Sulfate radical $\left(\mathrm{SO}_{4}^{-}\right)$-based advanced oxidation processes are known as a promising method for removal of organic contaminants present in water. One of the main sources of organic compounds is industrial wastewater, and their remediation is of basic significance to prevent water pollution. In recent years, $\mathrm{SO}_{4}^{--}$-based advanced oxidation processes (AOPs) have been extensively investigated for removal of water contaminants [1-3]. $\mathrm{SO}_{4}^{--}$is capable of degradation of organic contaminants into less harmful compounds or their mineralization into inorganic substances. $\mathrm{SO}_{4}{ }^{-}$can be generated using peroxymonosulfate $\left(\mathrm{HSO}_{5}^{-}, \mathrm{PMS}\right)$

*e-mail: ozlem.kartal@inonu.edu.tr or peroxydisulfate $\left(\mathrm{S}_{2} \mathrm{O}_{8}{ }^{2-}\right.$, $\left.\mathrm{PS}\right)$ when these oxidants are activated via thermal, chemical or UV irradiation methods [4-5]. Among them, UV/PS (Eq.1) [6-8], thermal/PS (Eq.1) [9-10], UV/PMS (Eq. 2) [11] and $\mathrm{Co}^{2+}$ PMS (Eq.3) [12] are widely used for generating $\mathrm{SO}_{4}^{--}$.

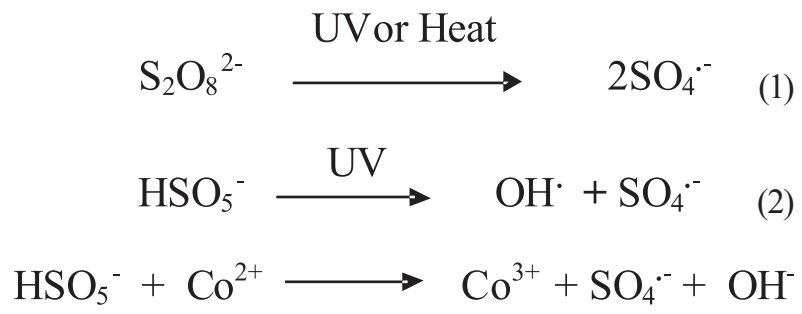

Hydroxyl radical $(\mathrm{OH})$ is another strong oxidant. $\mathrm{SO}_{4}$--based AOPs are preferred to conventional 
$\mathrm{OH}$-based AOPs because: (1) $\mathrm{SO}_{4}^{--}$has higher redox potential $(2.5-3.1 \mathrm{~V})$ than $\mathrm{OH} \cdot(2.8 \mathrm{~V}),(2) \mathrm{SO}_{4}^{--}$has longer half life (30-40 $\mu \mathrm{s})$ than $\mathrm{OH} \cdot\left(10^{-3} \mu \mathrm{s}\right)$, and (3) $\mathrm{SO}_{4}{ }^{-}$can oxidize organic compounds selectively while $\mathrm{OH} \cdot$ is not selective toward organic compounds [13-14].

Organic compounds (R) are degradated through $\mathrm{SO}_{4}{ }^{-}$chain reactions presented in Eqs. 4-7.

$$
\begin{gathered}
\mathrm{SO}_{4}^{{ }^{-}}+\mathrm{RH}_{2} \longrightarrow \mathrm{SO}_{4}{ }^{2-}+\mathrm{H}^{+}+\mathrm{RH}^{-} \\
\mathrm{RH}+\mathrm{S}_{2} \mathrm{O}_{8}{ }^{2-} \longrightarrow \mathrm{SO}_{4}{ }^{2-}+\mathrm{H}^{+}+\mathrm{SO}^{-} \\
\mathrm{SO}_{4}{ }^{--}+\mathrm{RH} \\
2 \mathrm{R} \longrightarrow \mathrm{R}+\mathrm{SO}_{4}{ }^{2-}+\mathrm{H}^{+} \\
\end{gathered}
$$

Since azo dyes have been widely used in the dying process of the textile industry, they constitute the largest groups of organic pollutants present in textile wastewater. Azo dyes have at least one $-\mathrm{N}=\mathrm{N}-$ azo bond linking aromatic rings in their molecular structure and are considered mostly as non-biodegradable compounds [15]. The textile industry is known to be the most polluting industry due to the consumption of nearly $21-377 \mathrm{~m}^{3}$ of water per ton of textile product and the presence of unfixed dyes [16]. Colored textile effluents with high chemical oxygen demand (COD) and low biochemical oxygen demand (BOD) values should be treated prior to discharge into water bodies. Although a number of treatment technologies classified as biological, chemical and physical for remediation of textile wastewater have been developed so far, they are found to be insufficient or require further treatments. Consequently, $\mathrm{SO}_{4}^{-}$-based AOPs are considered to be an efficient technology for treating azo dyes.

The objective of this study was to evaluate the decolorization and degradation of Reactive Red 239
(RR239), chosen as a model water contaminant by UV-C activated peroxydisulfate oxidation. The effect of process variables including initial $\mathrm{pH}$, initial dye concentration, $\mathrm{S}_{2} \mathrm{O}_{8}{ }^{2-}$ dosage and light intensity on decolorization of RR239 was investigated. Besides, decolorization and aromatic degradation performance of PS and PMS were compared in terms of electrical energy consumptions and cost.

\section{Experimental}

\section{Materials}

$\mathrm{Na}_{2} \mathrm{~S}_{2} \mathrm{O}_{8} \quad(\geq 99.9 \%, \quad$ Merck), oxone (KHSO $_{5} .0 .5 \mathrm{KHSO}_{4} .0 .5 \mathrm{~K}_{2} \mathrm{SO}_{4}$, Sigma-Aldrich), tert-butyl alcohol (TBA, 99\%, Merck), ethanol (EtOH, absolute $\geq 99.8 \%$, Sigma-Aldrich), $\mathrm{HCl}(37 \% \mathrm{w} / \mathrm{w}$, Merck) and $\mathrm{NaOH}$ (Sigma-Aldrich) were of analytical grade and used without further purification. RR239 was provided from DyStar and its properties are given in Table 1.

\section{Experimental Procedure}

All experiments were conducted in a cylindrical photoreactor equipped with a water jacket to hold the temperature of reaction medium at $25^{\circ} \mathrm{C}$. The photoreactor was illuminated by UV-C lamps (Ostram, G8T5/8W) with a total power of $16 \mathrm{~W}$. The reaction medium was stirred by a magnetic stirrer (IKA RH $\mathrm{KT} / \mathrm{C}$ ) during irradiation. $100 \mathrm{mg} \mathrm{dm}^{-3}$ stock solution was used to prepare RR239 solution at desired concentration. For each run, $500 \mathrm{ml}$ of RR239 solution at predetermined concentration was charged to the photoreactor and stirred for 10 minutes before the addition of $\mathrm{Na}_{2} \mathrm{~S}_{2} \mathrm{O}_{8}$. The initial $\mathrm{pH}$ of resulting solution was adjusted using $\mathrm{NaOH}$ or HCI solutions. Then, UV-C lamps were turned on to initiate the reaction. Samples taken from reaction medium at predetermined

Table 1. Characteristics of Reactive Red 239.

\begin{tabular}{|c|c|}
\hline Molecular Structure & 5-[[4-chloro-6-[4-(2-sulfooxyethylsulfonyl)anilino]-1,3,5-triazin-2-yl]amino]-3-[(1,5-disulfonaphthalen-2- \\
yl)hydrazinylidene]-4-oxonaphthalene-2,7-disulfonic acid
\end{tabular}


time intervals during the experiment were immediately analyzed by a double-beam Shimadzu UV-1800 UV Spectrophotometer concentration at maximum wavelength of $540 \mathrm{~nm}$. The decolorization and aromatic degradation efficiencies of the samples were calculated as follows (Eqs. 8 and 9):

$$
\text { Decolorization } \%=\frac{A_{0}(540 \mathrm{~nm})-\mathrm{A}(540 \mathrm{~nm})}{\mathrm{A}_{0}(540 \mathrm{~nm})} \times 100
$$

$$
\text { Degradation } \%=\frac{\mathrm{A}_{0}(289 \mathrm{~nm})-\mathrm{A}(289 \mathrm{~nm})}{\mathrm{A}_{0}(289 \mathrm{~nm})} \times 100
$$

...where $A_{0}$ and $A$ are initial and treated absorbance values of RR239 at corresponding wavelengths, respectively.

\section{Results and Discussion}

\section{Effect of Initial $\mathrm{pH}$}

The effect of initial $\mathrm{pH}$ on the decolorization of RR239 is shown in Fig. 1. It is clear that considerable decolorization efficiency was observed after 120 minutes of reaction time for all studied $\mathrm{pH}$ values. In acidic conditions, additional $\mathrm{SO}_{4}{ }^{-}$is generated according to Eqs. 10 and 11. But in the presence of excess $\mathrm{SO}_{4}^{-}$, chemical scavenging reactions (i.e., reactions between radical with radical (Eq. 12) or radical with radical scavengers (Eqs. 13 and 14) are favored instead of radical with RR239 [17-18].

$$
\begin{aligned}
& \mathrm{S}_{2} \mathrm{O}_{8}{ }^{2-}+\mathrm{H}^{+} \longrightarrow \mathrm{HS}_{2} \mathrm{O}_{8}{ }^{-} \\
& \mathrm{HS}_{2} \mathrm{O}_{8}{ }^{-} \longrightarrow \mathrm{SO}_{4}{ }^{-}+\mathrm{SO}_{4}{ }^{2-}+\mathrm{H}^{+} \\
& \mathrm{SO}_{4}{ }^{--}+\mathrm{SO}_{4}{ }^{--} \longrightarrow \mathrm{S}_{2} \mathrm{O}_{8}{ }^{2-} \\
& \mathrm{SO}_{4}{ }^{--}+\mathrm{S}_{2} \mathrm{O}_{8}{ }^{2-} \longrightarrow \mathrm{S}_{2} \mathrm{O}_{8}{ }^{--}+\mathrm{SO}_{4}{ }^{2-} \\
& \mathrm{SO}_{4}^{--}+\mathrm{H}_{2} \mathrm{O} \longrightarrow \mathrm{SO}_{4}^{2-}+\mathrm{OH}^{-}+\mathrm{H}^{+}
\end{aligned}
$$

In the case of neutral and basic conditions, $\mathrm{SO}_{4}$ generates $\mathrm{OH}$ via Eqs. 14 and 15 [19].

$$
\mathrm{SO}_{4}{ }^{-}+\mathrm{OH}^{-} \longrightarrow \mathrm{SO}_{4}{ }^{2-}+\mathrm{OH}^{\cdot}
$$

Accordingly, at low $\mathrm{pH}$ values, $\mathrm{SO}_{4}^{-{ }^{--}}$was the main reactive radical and from the results of Fig. 1 we can observe that scavenging reactions were not significant. Besides, decolorization of RR239 was not affected in the presence of $\mathrm{OH}$. Therefore, it can be concluded that initial $\mathrm{pH}$ of RR239 solution had no considerable effect

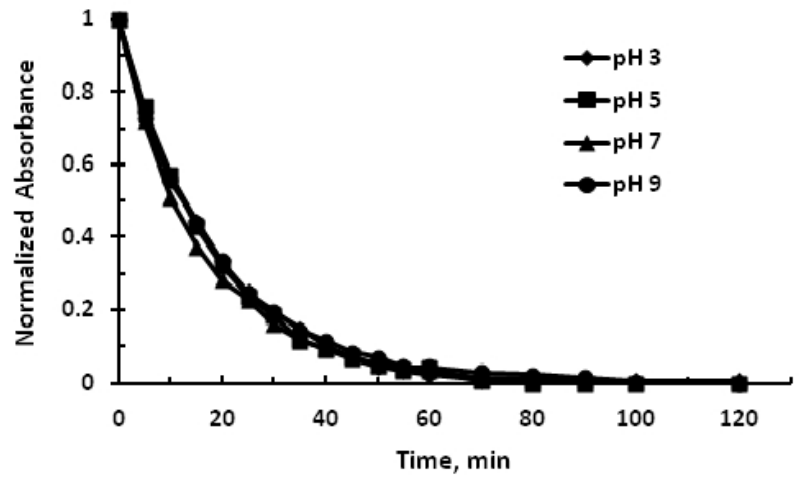

Fig. 1. Effect of $\mathrm{pH}$ on decolorization of RR239 [RR239] $=30 \mathrm{mg} \mathrm{dm}^{-3},\left[\mathrm{~S}_{2} \mathrm{O}_{8}{ }^{2-}\right]=2 \mathrm{mmol} \mathrm{dm}^{-3}$

on decolorization efficiency. It was also observed that $\mathrm{pH}$ of RR239 solution was decreased during reaction with all investigated $\mathrm{pH}$ values. This can be attributed to the generation of acidic products during degradation of RR239 and the release of $\mathrm{H}^{+}$as proposed in Eq. 14 . Similar results were recorded by Chen et al. [20].

\section{Effect of Initial Dye Concentration}

Effect of initial dye concentration on the decolorization of RR239 at initial $\mathrm{pH}$ of 5 was investigated over the range of $20-50 \mathrm{mg} \mathrm{dm}^{-3}$ at $2 \mathrm{mmol} \mathrm{dm}^{-3} \mathrm{~S}_{2} \mathrm{O}_{8}{ }^{2-}$ dosage. As can be seen from Fig. 2, decolorization efficiency decreased upon increasing initial RR239 concentration. This can be explained by the decrease in penetration of photons into dye solution at high concentration of RR239, thus yielding low $\mathrm{SO}_{4}^{--}$ formation. These observations were in agreement with studies reported in the literature [7-8].

\section{Effect of $\mathrm{S}_{2} \mathrm{O}_{8}{ }^{2-}$ Dosage}

Experiments were conducted at different $\mathrm{S}_{2} \mathrm{O}_{8}{ }^{2-}$ doses ranging from 0 to $3 \mathrm{mmol} \mathrm{dm}^{-3}$ at initial RR239 concentration of $40 \mathrm{mg} \mathrm{dm}^{-3}$. As can be deduced from Fig. 3, an increase in $\mathrm{S}_{2} \mathrm{O}_{8}{ }^{2-}$ dosage up

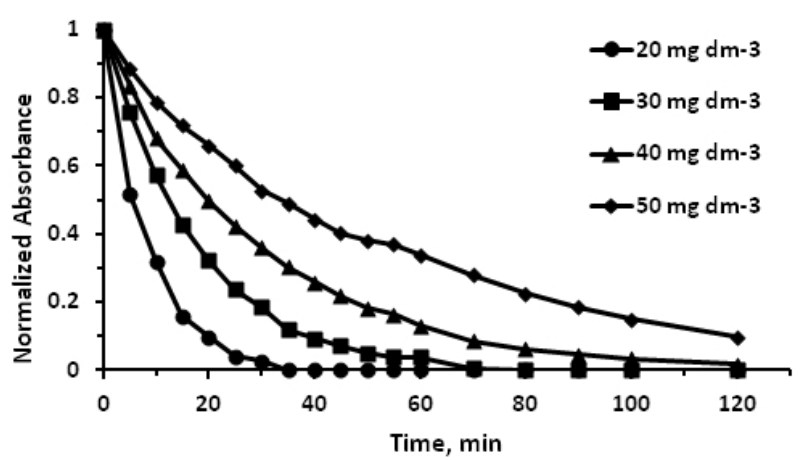

Fig. 2. Effect of initial dye concentration on decolorization of RR239 $\mathrm{pH}=5,\left[\mathrm{~S}_{2} \mathrm{O}_{8}{ }^{2-}\right]=2 \mathrm{mmol} \mathrm{dm}^{-3}$ 


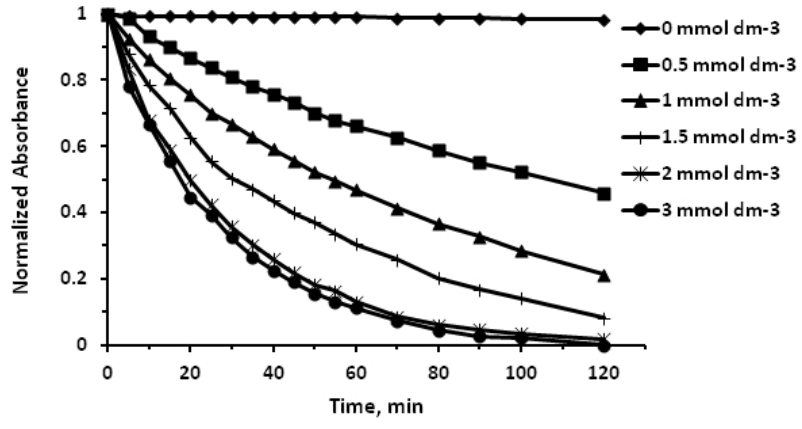

Fig. 3. Effect of $\mathrm{S}_{2} \mathrm{O}_{8}{ }^{2-}$ dosage on decolorization of RR239 $\mathrm{pH}=5, \quad[\mathrm{RR} 239]=40 \mathrm{mg} \mathrm{dm}^{-3}$

to $2 \mathrm{mmol} \mathrm{dm}^{-3}$ resulted in a significant improving effect on decolorization efficiency of RR239 due to the formation of more sulfate and hydroxyl radicals. However, no observable increase in decolorization efficiency of RR239 was obtained beyond $2 \mathrm{mmol} \mathrm{dm}^{-3}$ $\mathrm{S}_{2} \mathrm{O}_{8}{ }^{2-}$ dosages. This is because an excess amount of $\mathrm{S}_{2} \mathrm{O}_{8}{ }^{2-}$ favored radical scavenging reactions given in Eqs. 12 and 13 [21]. Besides, an appreciable decolorization was not observed in the absence of $\mathrm{S}_{2} \mathrm{O}_{8}{ }^{2-}$ (i.e., direct photolysis). Accordingly, the optimum dosage of $\mathrm{S}_{2} \mathrm{O}_{8}^{2-}$

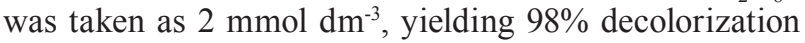
efficiency within 120 minutes of reaction time.

\section{Effect of UV Lamp Power}

The effect of UV lamp power on decolorization efficiency of RR239 was investigated in the range of $0-16 \mathrm{~W}$ with $40 \mathrm{mg} \mathrm{dm}^{-3} \mathrm{RR} 239$ initial concentration and $2 \mathrm{mmol} \mathrm{dm}^{-3} \mathrm{~S}_{2} \mathrm{O}_{8}{ }^{2-}$ dosage. Fig. 4 illustrates that decolorization efficiency improved from $37 \%$ to $98 \%$ with increasing UV lamp power from 8 to $16 \mathrm{~W}$, respectively. This can be attributed to the promotion of photolysis of $\mathrm{S}_{2} \mathrm{O}_{8}{ }^{2-}$ ions, thus enhancing the formation of sulfate radical. Although the $\mathrm{S}_{2} \mathrm{O}_{8}{ }^{2-}$ ion is a strong oxidant having an oxidation potential of $2.12 \mathrm{~V}$, in the absence of UV lamp decolorization of RR239 it was not observed during 120 minutes of reaction time due to the slow oxidation reaction of the $\mathrm{S}_{2} \mathrm{O}_{8}^{2-}$ ion.

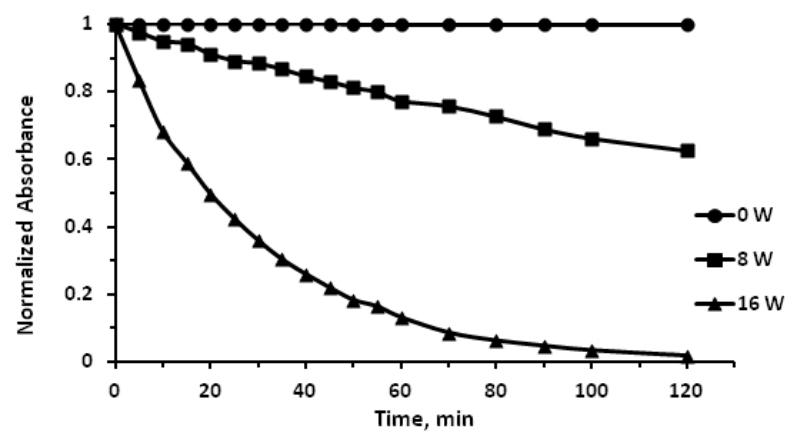

Fig. 4. Effect of lamp power on decolorization of RR239 $\left[\mathrm{S}_{2} \mathrm{O}_{8}{ }^{2-}\right]=2 \mathrm{mmol} \mathrm{dm}^{-3},[\mathrm{RR} 239]=40 \mathrm{mg} \mathrm{dm}^{-3}, \mathrm{pH}=5$

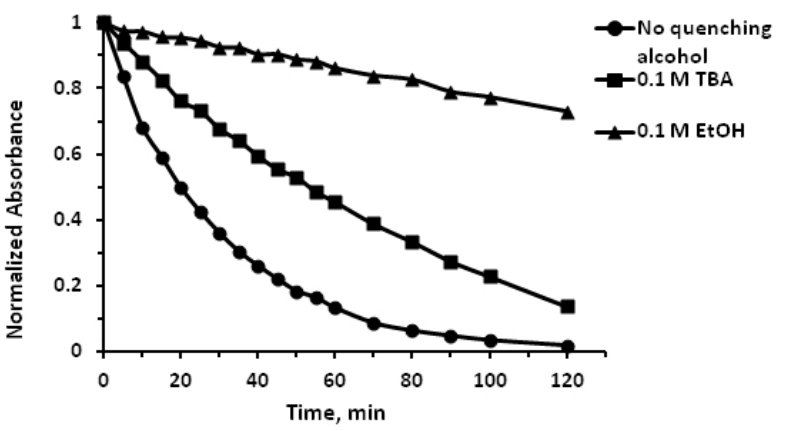

Fig. 5. Decolorization of RR239 in the presence of alcohols $\left[\mathrm{S}_{2} \mathrm{O}_{8}{ }^{2-}\right]=2 \mathrm{mmol} \mathrm{dm}^{-3},[\mathrm{RR} 239]=40 \mathrm{mg} \mathrm{dm}^{-3}, \mathrm{pH}=5$

\section{Radical Quenching Studies}

It can be reasonably inferred from Eqs. 14 and 15 that $\mathrm{OH}$ can also be present in reaction solution of $\mathrm{S}_{2} \mathrm{O}_{8}{ }^{2-} / \mathrm{UV}$ system. Therefore, determining the dominant radical by quenching studies is of basic importance in $\mathrm{SO}_{4}$--based AOPs. Alcohol with alpha hydrogen such as ethyl alcohol $(\mathrm{EtOH})$ reacts with these two radicals at high rates and alcohol without alpha hydrogen such as tert-butyl alcohol (TBA) reacting with $\mathrm{OH}$ faster than $\mathrm{SO}_{4}^{-}$. Therefore, these alcohols were used in quenching studies as radical scavengers [22-23]. The result of quenching studies was given in Fig. 5. When TBA was added into reaction at 50:1 molar ratio of alcohol vs. oxidant, corresponding to $0.1 \mathrm{M}$ alcohol, decolorization efficiency decreased from 98 to $86 \%$. Since only $\mathrm{OH}$. was scavenged by TBA, decolorization of RR239 was achieved by $\mathrm{SO}_{4}^{--}$in the case of the addition of TBA. When EtOH was added into reaction at the same ratio, $27 \%$ decolorization efficiency was obtained, indicating that both radicals were scavenged by EtOH. It can be inferred from these results that $\mathrm{SO}_{4}^{-{ }^{-}}$is the dominant radical.

\section{UV-Visible Spectral Changes of RR239}

UV-visible spectra of RR239 measured over the wavelength range of 190-800 $\mathrm{nm}$ during $120 \mathrm{~min}$ of irradiation are shown in Fig. 6. Two main peaks at 289 and $540 \mathrm{~nm}$ appeared in the spectrum. The absorbance peak at $540 \mathrm{~nm}$ in visible region corresponds to a chromophoric group of dye (i.e., azo linkage), while peak in the UV region at 289 is attributed to benzene ring. A decrease in absorbance at $540 \mathrm{~nm}$ indicated the cleavage of $-\mathrm{N}=\mathrm{N}$ - bond resulting in decolorization of RR239. Aromatic degradation of RR239 was monitored by following a decrease in absorbance at 289 . It was observed from Fig. 7 that $98 \%$ and $70 \%$ decolorization and aromatic degradation efficiencies were obtained upon 120 min of irradiation time, respectively. Almost complete decolorization of RR239 was observed at $120 \mathrm{~min}$, while longer irradiation time was required for degradation. $\mathrm{SO}_{4}^{-}$reacts with organic compounds by electron transfer. Therefore, degradation of RR239 via 


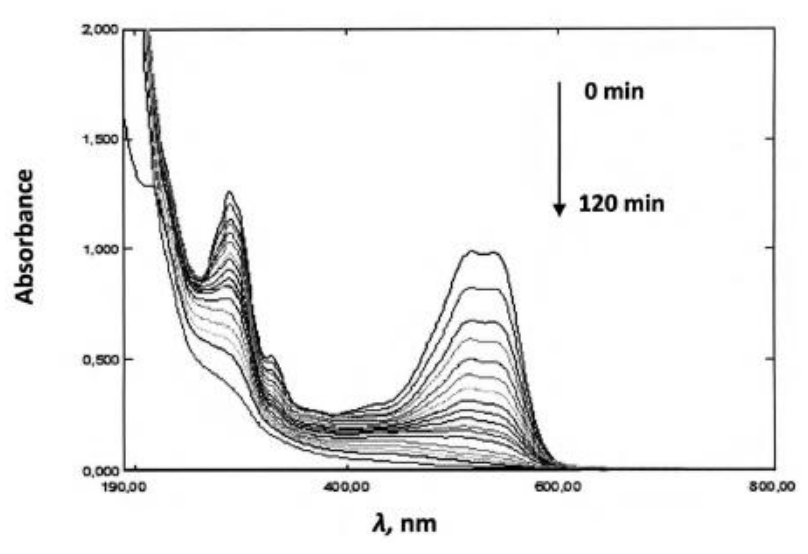

Fig. 6. Changes of the absorption spectra of RR239 solution with time $\left[\mathrm{S}_{2} \mathrm{O}_{8}{ }^{2-}\right]=2 \mathrm{mmol} \mathrm{dm}^{-3},[\mathrm{RR} 239]=40 \mathrm{mg} \mathrm{dm}^{-3}, \mathrm{pH}=5$

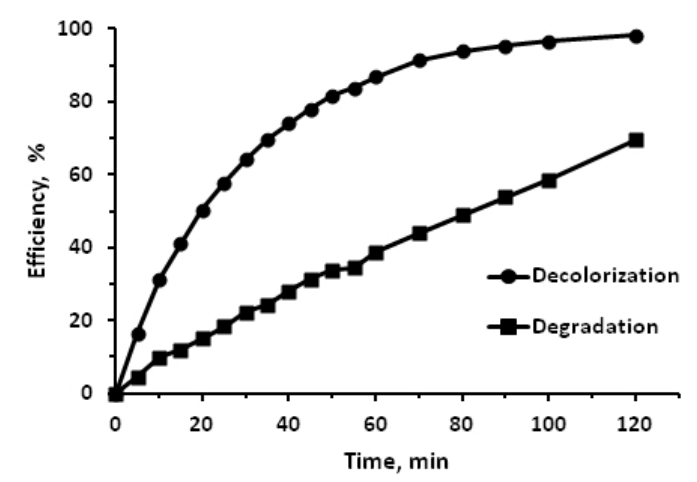

Fig. 7. Decolorization and aromatic degradation of RR239 $\left[\mathrm{S}_{2} \mathrm{O}_{8}{ }^{2-}\right]=2 \mathrm{mmol} \mathrm{dm}^{-3},[\mathrm{RR} 239]=40 \mathrm{mg} \mathrm{dm}^{-3}, \mathrm{pH}=5$

$\mathrm{SO}_{4}^{--}$precedes through successive oxidation steps of abstraction of electrons from aromatic rings [24].

$$
\begin{gathered}
\text { Comparison Performance of } \mathrm{S}_{2} \mathrm{O}_{8}{ }^{2-} / \mathrm{UV} \\
\text { and } \mathrm{HSO}_{5}^{-} / \mathrm{UV} \text { Systems }
\end{gathered}
$$

PS is known to be a symmetric oxidant with respect to peroxide bond (-O-O-), while PMS is an asymmetric oxidant around the peroxide bond. Therefore, activation of PS and PMS under UV-C illumination yielded two $\mathrm{SO}_{4}^{--}$, according to Eq. 1 and one $\mathrm{SO}_{4}^{--}$and one $\mathrm{OH}$, according to Eq. 2, respectively [11]. Decolorization and aromatic degradation performance of these oxidants were compared in terms of electrical energy consumption and cost. A figure of merit approach can be applied to determine electrical energy consumption for one order of magnitude treatment of pollutants in a unit volume for AOPs [8, 25-26]. Electrical energy per order $(\mathrm{EE} / \mathrm{O})$ for low concentration of pollutants is calculated using Eq. 16:

$$
\frac{E E}{O}=\frac{P t 1000}{V 60 \log \frac{C_{o}}{C}}
$$

...where $P$ is input power to the process $(\mathrm{kW}), t$ is irradiation time (min), and $V$ is the volume of treated water $\left(\mathrm{dm}^{3}\right)$.

The pseudo first-order kinetic model given in Eq. 17 is applied for decolorization and aromatic degradation of RR239 [27-28].

$$
\ln \frac{C_{o}}{C}=k_{a p p} t
$$

...where $\mathrm{C}_{\mathrm{o}}$ and $\mathrm{C}$ are initial and treated dye concentrations, $\mathrm{k}_{\text {app }}$ is apparent first-order rate constant and $t$ is reaction time.

Hence, Eq. 18 is obtained by combining Eqs. 16 and 17.

$$
E_{E O}=\frac{38.4 P}{V k_{a p p}}
$$

As can be seen in Fig. 8, a good linearity of $\ln$ $(\mathrm{Co} / \mathrm{C})$ versus $t$ plots was obtained for PS, yielding $k_{a p p}$ values as 0.0338 and $0.0092 \mathrm{~min}^{-1}$ for decolorization and aromatic degradation, respectively. Similarly, as is evident from Fig. 9, linear plots of $\ln (\mathrm{Co} / \mathrm{C})$ versus $t$ for PMS were observed and $k_{\text {app }}$ values were found to be as 0.0155 and $0.0056 \mathrm{~min}^{-1}$ for decolorization

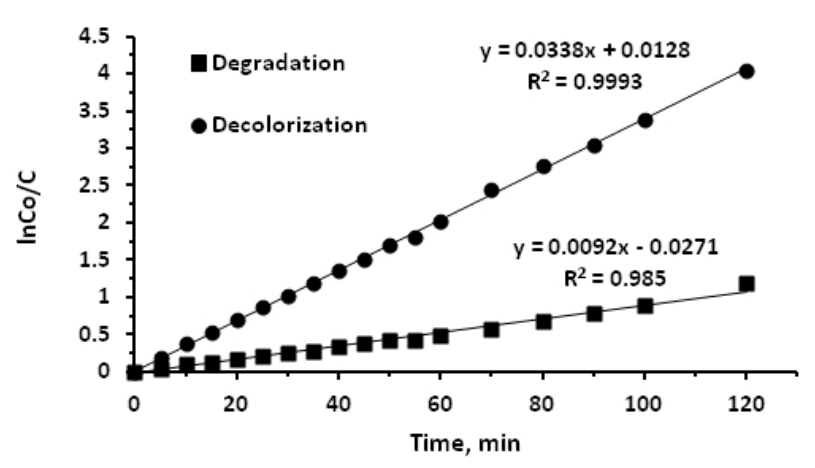

Fig. 8. Kinetics of decolorization and aromatic degradation of RR239 in a PS/UV system

$\left[\mathrm{S}_{2} \mathrm{O}_{8}{ }^{2-}\right]=2 \mathrm{mmol} \mathrm{dm}^{-3},[\mathrm{RR} 239]=40 \mathrm{mg} \mathrm{dm}^{-3}, \mathrm{pH}=5$

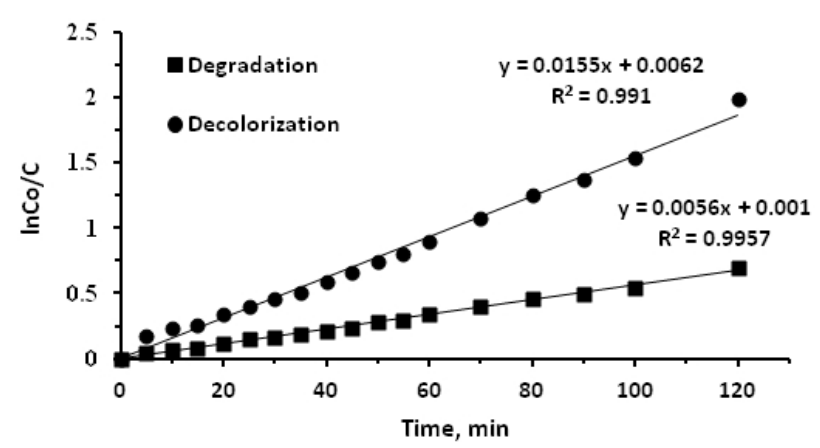

Fig. 9. Kinetics of decolorization and aromatic degradation of RR239 in a PMS/UV system

$\left[\mathrm{HSO}_{5}^{-}\right]=2 \mathrm{mmol} \mathrm{dm}^{-3},[\mathrm{RR} 239]=40 \mathrm{mg} \mathrm{dm}^{-3}, \mathrm{pH}=5$ 


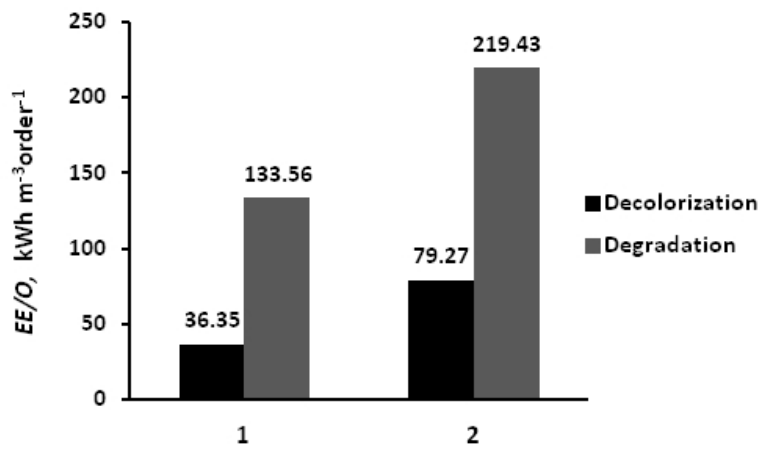

Fig. 10. EE/O values for decolorization and degradation of RR239

1. PS/UV-C 2. PMS/UV-C

and aromatic degradation, respectively. The electrical energy consumptions for decolorization and aromatic degradation of $0.5 \mathrm{dm}^{3}$ RR239 solution in PS/UV-C and PMS/UV-C systems are given in Fig. 10. The EE/O values implied that requirement of electrical energy for decolorization of RR239 was lower than that of for aromatic degradation under investigated conditions for both systems. As expected, less energy was consumed for decolorization and aromatic degradation in the $\mathrm{PS} / \mathrm{UV}-\mathrm{C}$ system in comparison to the PMS/UV-C system. This can be attributed to the presence of $\mathrm{SO}_{4}{ }^{-}$as a dominant radical in $\mathrm{PS} / \mathrm{UV}-\mathrm{C}$, as can be followed by quenching studies.

The cost of electrical energy for decolorization and aromatic degradation of RR239 in PS/UV-C and PMS/ UV-C systems was calculated considering one order of magnitude treatment of RR239. The cost of electricity per $\mathrm{kWh}$ in Turkey is taken as $0.0467 € / \mathrm{kWh}$. According to Fig. 11, the maximum cost of electrical energy was obtained for decolorization and aromatic degradation of RR239 in a PMS/UV-C system. Electrical energy cost constitutes considerable fraction of operating cost of AOPs. Therefore, determining an efficient and cost-effective treatment method based on the cost of electrical energy is significant. Salari et al. [8] calculated the electrical energy per order values for decolorization

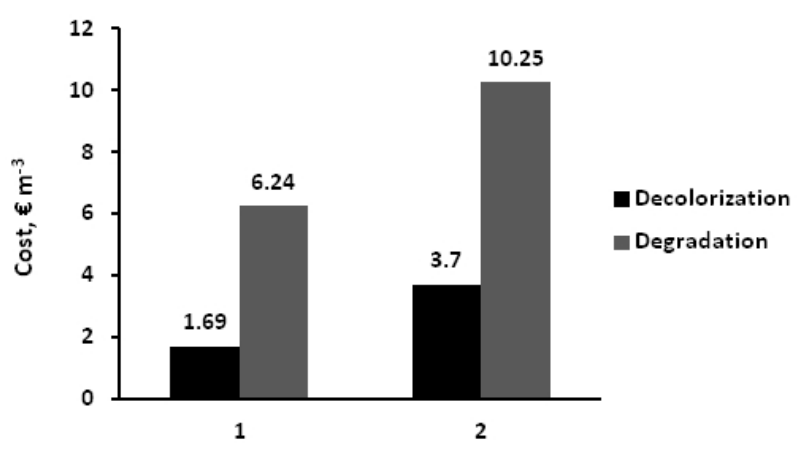

Fig. 11. Cost of electrical energy for decolorization and degradation of RR239

1. PS/UV-C 2. PMS/UV-C of $20 \mathrm{mg} \mathrm{dm}^{-3}$ C.I. Basic Yellow 2 dye solution using $\mathrm{UV} / \mathrm{S}_{2} \mathrm{O}_{8}{ }^{2-}$ process in a rectangular continuous photoreactor, and found that as $\mathrm{S}_{2} \mathrm{O}_{8}{ }^{2-}$ concentration increases, energy per order values decrease. Khataee [29] reported that $29.43 \mathrm{kWh} \mathrm{m}^{-3}$ order $^{-1}$ electrical energy was required for decolorization of $10 \mathrm{mg} \mathrm{dm}^{-3}$ C.I. Basic Red 46 mono azo dye under optimized conditions using a $\mathrm{UV} / \mathrm{S}_{2} \mathrm{O}_{8}{ }^{2-}$ process, and related electrical energy cost was found to be $\$ 0.68 \mathrm{~m}^{-3}$. Sharma et al. [30] investigated the removal and mineralization $0.22 \mathrm{mM}$ Bisphenol A using $\mathrm{UV} / \mathrm{H}_{2} \mathrm{O}_{2}$ and $\mathrm{UV} / \mathrm{S}_{2} \mathrm{O}_{8}{ }^{2-}$ oxidation systems. $\quad \mathrm{UV} / \mathrm{S}_{2} \mathrm{O}_{8}{ }^{2-}$ oxidation system required lower electrical energy $\left(307 \mathrm{kWh} \mathrm{m}^{-3}\right)$ than the $\mathrm{UV} / \mathrm{H}_{2} \mathrm{O}_{2}$ system $\left(509 \mathrm{kWh} \mathrm{m}^{-3}\right)$ under optimum operating conditions.

\section{Conclusions}

In this study, decolorization of RR239 by UVactivated persulfate oxidation was investigated. Effects of initial $\mathrm{pH}$ of RR239 solution, initial dye concentration, $\mathrm{S}_{2} \mathrm{O}_{8}^{2-}$ dosage and lamp power were examined. The experimental results revealed that decolorization of RR239 increased with increasing $\mathrm{S}_{2} \mathrm{O}_{8}{ }^{2-}$ dosage and lamp power, while decolorization efficiency decreased upon increasing initial RR239 concentration. However, initial pH of RR239 solution had no considerable effect on decolorization efficiency. As observed in quenching studies, $\mathrm{SO}_{4}^{-{ }^{-}}$is the dominant radical in the $\mathrm{S}_{2} \mathrm{O}_{8}{ }^{2-} / \mathrm{UV}$ system. As expected, longer irradiation time was required for aromatic degradation. The electrical energy consumptions of decolorization and aromatic degradation of RR239 in PS/UV-C and PMS/UV-C systems was calculated. Considering one order of magnitude treatment of RR239, the cost of electrical energy for decolorization and aromatic degradation of the RR239 in PS/UV-C system was found to be 1.69 and $6.24 €^{-3}$, respectively, while the cost of electrical energy for those in the $\mathrm{PMS} / \mathrm{UV}-\mathrm{C}$ system was calculated as 3.70 and $10.24 €^{-3}$, respectively. According to the results obtained in this study, decolorization and aromatic degradation of RR239 via $\mathrm{SO}_{4}^{--}$were efficiently achieved in the $\mathrm{S}_{2} \mathrm{O}_{8}{ }^{2-} / \mathrm{UV}$ system.

\section{Conflict of Interest}

The author declares no conflict of interest.

\section{References}

1. YANG S., WANG P., YANG X., SHAN L., ZHANG W., SHAO X., NIU R. Degradation efficiencies of azo dye Acid Orange 7 by the interaction of heat, UV and anions with common oxidants: Persulfate, peroxymonosulfate and hydrogen peroxide. J. Hazard. Mater., 179, 552, 2012. 
2. LAU T.M., CHU W., GRAHAM N.J.D. The aqueous degradation of butylated hydroxyanisole by $\mathrm{UV} / \mathrm{S}_{2} \mathrm{O}_{8}^{2}$ : Study of reaction mechanisms via dimerization and mineralization. Environ. Sci. Technol., 41, 613, 2007.

3. TAN C., GAO N., DENG Y., AN N., DENG J. Heatactivated persulfate oxidation of diuron in water. Chem. Eng. J., 203, 294, 2012.

4. CHEN J., ZHANG L., HUANG T., LI W., WANG, Y., WANG, Z. Decolorization of azo dye by peroxymonosulfate activated by carbon nanotube: Radical versus non-radical mechanism. J. Hazard. Mater., 320, 571, 2016.

5. ISMAIL L., FERRONATO C., FINE L., JABER F., CHOVELONA J.M. Elimination of sulfaclozine from water with $\mathrm{SO}_{4}^{-}$radicals: Evaluation of different persulfate activation methods. Appl. Catal. B, 201, 573, 2017.

6. MAHDI-AHMED M., CHIRON S. Ciprofloxacin oxidation by UV-C activated peroxymonosulfate in wastewater. J. Hazard. Mater., 265, 41, 2014.

7. FRONTISTIS Z., HAPESHI E., FATTA-KASSINOS D., MANTZAVINOS D. Ultraviolet -activated persulfate oxidation of methyl orange: a comparison between artificial neural networks and factorial design for process modeling. Photochem. Photobiol. Sci., 14, 528, 2015.

8. SALARI D., NIAERI A., ABER S., RASOULIFARD M. H. The photooxidative destruction of C.I. Basic Yellow 2 using $\mathrm{UV} / \mathrm{S}_{2} \mathrm{O}_{8}{ }^{2-}$ process in a rectangular continuous photoreactor. J. Hazard. Mater., 166, 61, 2009.

9. GHAUCH A., TUQAN A. M. Oxidation of bisoprolol in heated persulfate $/ \mathrm{H}_{2} \mathrm{O}$ systems: Kinetics and products. Chem. Eng. J., 183, 162, 2012.

10. MORA V.C., ROSSO J.A., LE ROUX G.C., MARTIRE D.O., GONZALEZ M.C. Thermally activated peroxydisulfate in the presence of additives: A clean method for the degradation of pollutants. Chemosphere, 75, 1405, 2009.

11. ANTONIOU M.G., DE LA CRUZ A.A., DIONYSIOU D.D. Degradation of microcystin-LR using sulfate radicals generated through photolysis, thermolysis and $\mathrm{e}^{-}$transfer mechanisms. App. Catal. B, 96, 290, 2010.

12. NIPSITAKIS G.P., DIONYSIOU D.D. Radical generation by the interaction of transition metals with common oxidants. Environ. Sci. Technol., 38, 3705, 2004.

13. HU P., LONG M. Cobalt-catalyzed sulfate radical-based advanced oxidation: A review on heterogeneous catalysts and applications. App.Catal. B, 181, 103, 2016.

14. NASSERI S., MAHVI A.H., SEYEDSALEHI M., YAGHMAEIAN K., NABIZADEH R., ALIMOHAMMADI M., SAFARI G.H. Degradation kinetics of tetracycline in aqueous solutions using peroxydisulfate activated by ultrasound irradiation: Effect of radical scavenger and water matrix. J. Mol. Liq., 241, 704, 2017.

15. ULLAH I., ALİ S., HANİF M.A., ZİA. M.A. Photocatalytic activity of $\mathrm{Al}_{2} \mathrm{O}_{3} \cdot \mathrm{Fe}_{2} \mathrm{O}_{3}$ synthesized by ultrasonic-assisted mechanical stirring. Pol. J. Environ. Stud., 26, 2777, 2017.

16. ASGHAR A., RAMAN A.A.A., DAUD W.M.A.W. Advanced oxidation processes for in-situ production of hydrogen peroxide/hydroxyl radical for textile wastewater treatment: a review. J. Clean. Prod. 87, 826, 2015.

17. FANG G.-D., DIONYSIOU D. D., ZHOU D.-M., WANG Y., ZHU X.- D., FAN J.- X., CANG L., WANG Y.- J. Transformation of polychlorinated biphenyls by persulfate at ambient temperature. Chemosphere, 90, 1573, 2013.

18. SAIEN J., SOLEYMANI A.R., SUN J.H. Parametric optimization of individual and hybridized AOPs of $\mathrm{Fe}^{2+} / \mathrm{H}_{2} \mathrm{O}_{2}$ and $\mathrm{UV} / \mathrm{S}_{2} \mathrm{O}_{8}{ }^{2-}$ for rapid dye destruction in aqueous media. Desalination, 279, 298, 2011.

19. LIANG C., WANG Z.- S., BRUELL C.J. Influence of $\mathrm{pH}$ on persulfate oxidation of TCE at ambient temperatures. Chemosphere, 66, 106, 2007.

20. CHEN X., XUE Z., YAO Y., WANG W., ZHU F., HONG C. Oxidation degradation of Rhodamine $B$ in aqueous by $\mathrm{UV} / \mathrm{S}_{2} \mathrm{O}_{8}{ }^{2-}$ treatment system. Int. J. Photoenergy, 2012, Article ID 754691, 2012.

21. OLMEZ-HANCI T., ARSLAN-ALATON İ. Comparison of sulfate and hydroxyl radical based advanced oxidation of phenol. Chem. Eng. J. 224, 10, 2013.

22. RASTOGI A., AL-ABED S.R., DIONYSIOU D.D. Sulfate radical-based ferrous-peroxymonosulfate oxidative system for PCBs degradation in aqueous and sediment systems. App. Catal. B, 85, 171, 2009.

23. DING Y., ZHU L., WANG N., TANG H. Sulfate radicals induced degradation of tetrabromobisphenol $\mathrm{A}$ with nanoscaled magnetic $\mathrm{CuFe}_{2} \mathrm{O}_{4}$ as a heterogeneous catalyst of peroxymonosulfate. App. Catal. B, 129, 153, 2013.

24. ANIPSITAKIIS G.P., DIONYSIOU D.D., GONZALEZ M.A. Cobalt-mediated activation of peroxymonosulfate and sulfate radical attack on phenolic compounds. Implications of chloride ions. Environ. Sci. Technol., 40, 1000, 2006.

25. SAIEN J., MORADI V., SOLEYMANI A.-R. Investigation of a jet mixing photo-reactor device for rapid dye discoloration and aromatic degradation via $\mathrm{UV} / \mathrm{H}_{2} \mathrm{O}_{2}$ process. Chem. Eng. J., 183, 135, 2012.

26. KHATAEE A.R., PONS M.N., ZAHRAA O. Photocatalytic degradation of three azo dyes using immobilized $\mathrm{TiO}_{2}$ nanoparticles on glass plates activated by UV light irradiation: Influence of dye molecular structure. J. Hazard. Mater., 168, 451, 2009.

27. WANG P., YANG S., SHAN L., NIU R., SHAO $\mathrm{X}$. Involvements of chloride ion in decolorization of Acid Orange 7 by activated peroxydisulfate or peroxymonosulfate oxidation .J. Environ. Sci., 23, 1799, 2011.

28. CHEN J., GAO N., LU X., MENG M., GU Z., JIANG C., WANG Q. Degradation of 2,4-dichlorophenol from aqueous using UV activated persulfate: kinetic and toxicity investigation. RSC Adv., 6, 100056, 2016.

29. KHATAEE A.R. Application of central composite design for the optimization of photodestructionof a textile dye using UV/S $\mathrm{S}_{2} \mathrm{O}_{8}{ }^{2-}$ process. Pol. J. Chem.Tech., 11, 38, 2009.

30. SHARMA J., MISHRA I.M., KUMAR V., Degradation and mineralization of Bisphenol A (BPA) in aqueous solution using advanced oxidation processes: $\mathrm{UV} / \mathrm{H}_{2} \mathrm{O}_{2}$ and $\mathrm{UV} / \mathrm{S}_{2} \mathrm{O}_{8}{ }^{2-}$ oxidation systems. J. Environ. Manage., 156, 266, 2015. 